\title{
Evaluative study of the effectiveness of the administrative performance of the head teachers at primary level in
}

\author{
District Karak
}

\section{(Khyber Pukhtunkhwa) Pakistan}

\author{
Qaiser Suleman \\ M.Phil (Education) Scholar, Kohat University of Science \& Technology Kohat, Khyber \\ Pukhtunkhwa, (Pakistan)
}

Tel: +92-3139043454,+92-927303028, E-Mail: Look_for_reality@yahoo.com

Irfan Lodhi

Training Advisor

Human Resource Management Academic Research Society

Received: August 12, 2011 Accepted: September 14, $2011 \quad$ DOI: 10.5296/jpag.v1i2.960

\begin{abstract}
The study was conducted to investigate the effectiveness of the administrative performance of the head teachers at primary level in District Karak. The main objectives of the study were; to evaluate the administrative performance of the head teachers; and to diagnose the major areas of strength and weakness of head teachers at primary level. All the teachers at primary level in District Karak constituted the population of the study. Only five hundred and twenty primary school teachers at the rate of $10 \%$ of the total were selected as sample of the study. The study was descriptive in nature. A questionnaire was developed as a research instrument for the collection of data. After analysis of data, the researcher arrived at results that the administrative performance of the head teachers at primary level is very poor, ineffective and objectionable. Majority of the head teachers have no administrative and leadership qualities and they have no interest in the school affairs.

Keywords: Administration, educational administration, effectiveness of the administrative performance of the head teachers at primary level.
\end{abstract}




\section{Introduction}

Primary education is playing a fundamental and crucial role in shaping the future status of the students. Therefore, it is imperative for a nation to strengthen and improve the standard of primary education. Quality primary education depends upon effective administrators and competent teachers. A good administrator can change the school atmosphere and make it favourable for effective teaching learning process. Being a teacher, it is my own observation that the quality of primary education is collapsing day by day due to ineffective and poor administration.

The word administration has been derived from the Latin word "Minister" which means service i.e., work devoted for the good of people. It is generally concerned with the business, an institution, an army or a factory etc. Administration is the essential and fundamental part of any organization, which provides a favourable environment for the development and growth of the society or the nation or an individual. The education is process which produces capabilities in individual enabling him to control his environment and fulfill his responsibilities (Campbell, 1962). Administration in any organization or association is comprised of a number of rational functions i.e. planning, organizing, coordinating, evaluating, delegating, controlling and so on. These functions are generally thought identical with leadership and this administrative leadership is considered as some thing to be applied on the association in such a way the organizational goals are more efficiently pursued (Sharma, 1994).

Educational administration means the administration which is concerned with the educational affairs. According to Kenneth (1984), educational administration is always concerned with management of things as well as human relationship based on a body of basic principles and aiming at educating the children and the youth. Educational administration has to undertake a number of functions like planning, organizing, directing and motivating, controlling, coordinating decision making, evaluating and recording and reporting etc. in order to make the education process more effective.

\section{Review of Related Literature}

Administration is defined in various ways depending upon the viewpoint, beliefs and intellectual capacity of the definer. The word administration has been derived from the Latin word Minister which means service, i.e., work dedicated for the good of others (Gupta, 1987).

Administration is a fundamental part of any organization and as a social process concerned with identifying, maintaining, motivation, controlling and unifying formally and informally organized human and material resources within an integrated system designed particularly to attain predetermined objectives (Musaazi, 1987).

The most important purpose of educational administration or educational management is to give assistance in attaining the objectives of an organization or an institution. Any system or organization will not be able to secure the desired results or to reach the target unless administration or management of education is enhanced or it is geared to the new emerging 
needs and challenges (Mohanty, 1998).

Good education is the result of good administration. Administration is not simply a managerial and administrative occupation but a rapidly developing profession. Through professional training, internship teaching and minor administrative experience, acquired ability to shape education to changing social trends, use of scientific test and research results, democratic leadership of personnel and the practice of basing procedures on established principles and doctrines, the administrators are building a complete and full-fledged professional service (Hunt and Pierce, 1958).

The success of any institution in attaining its goals and objectives depends on its principal administrator, other wise known as the principal acting particularly his supervisory functions. For educational supervision is the thrust of all established school. Hence, the importance of supervision in today's educational system cannot be overemphasized (Akpa, 1999). Presently the teaching force is weak and the standard of performance is also low. This is a sign too that the standard of supervisory practice is not excellent.

Administration determines the smooth and efficiently working of educational structure. Educational demonstration is responsible for the direction, control and management of all matters relating to school affairs (Government of Pakistan, 1998).

Our society is changing rapidly, so new techniques are being assumed in education to meet the needs and demands of the society. Therefore, education has become more important in the modern world and is essential for the economic development and defense of Pakistan. If a nation does not concentrate sufficient attention to education, it will be committed suicide in a slow manner until disaster overwhelms it. It is a hard fact that education is a complex and highly specialized field and its efficient administration requires technical competence, administrative ability and understanding of the educational development (Khalid, 1998).

\subsection{Types of Administration}

In education, there are three concepts of educational administration about education i.e., the authoritarian, the laissez-Faire and the democratic.

\subsubsection{The Authoritarian or Aristocratic}

This type of administration is almost executed in police department. The administrators are not bothered to listen to his subordinates. He believes threatening and black mailing. They do not accept the proposals rendered by his staff or subordinates. They think that they can do everything himself. They are so autocratic that even they reject useful proposals with sarcastic remarks. Sometimes they become angry on such useful proposals. They also criticize encouraging remarks, eventually employee or subordinates felt insulted and discouraged.

\subsubsection{The Laissez- Faire}

In this type of administration, the administrator has a very lose control and command over his subordinate. Actually, in this type of administration, professionally sound or unskilled 
subordinate constantly interfere in the affairs. As a result, the administrator becomes disheartened and so he does not take interest in educational affairs. He leaves everything on his own and thus administration is surrounded by unnecessarily less professional interference result in total failure in term of quality education (Musaazi, 1998).

\subsubsection{The Democratic}

This type of educational administration is considered a good educational administration which assists subordinates or staff, especially workers, depending upon themselves and not upon others. In the same administration, the administrator tries to understand his subordinates or workers problems and then tries to find out satisfactory and suitable solution according to the requirement of the subordinates or staff (Badar and Akhtar, 1991)

\section{Objectives of the Study}

Objectives of the study were:

1. To evaluate the administrative performance of the head teachers at primary level.

2. To diagnose the major areas of strength and weakness of the administrative performance of the head teachers at primary level.

\section{Methodology}

\subsection{Population}

All the teachers at primary level in District Karak constituted the population of the study

\subsection{Sample}

Only five hundred and twenty primary school teachers were selected as sample of the study.

\subsection{Research Instrument}

The study was descriptive in nature. A questionnaire was developed as a research instrument for the collection of data.

\section{Results}

Table No.01

Is your head teacher democratic in authority?

\begin{tabular}{|l|l|l|l|l|}
\hline No. of Teachers & Yes & No & Yes \%age & No \%age \\
\hline 520 & 202 & 318 & 38.85 & 61.15 \\
\hline
\end{tabular}

Analysis: The table shows that $38.85 \%$ teachers responded that their head teachers are democratic in authority and $61.15 \%$ responded that their head teachers are not democratic in authority. 


\section{Table No.02}

Is your head teacher has a good relation with you and other subordinates?

\begin{tabular}{|l|l|l|l|l|}
\hline Teachers & Yes & No & $\begin{array}{r}\text { Yes } \\
\text { \% age }\end{array}$ & No \%age \\
\hline 520 & 309 & 211 & 59.42 & 40.58 \\
\hline
\end{tabular}

Analysis: The table shows that $59.42 \%$ teachers responded that their head teachers have a good relation with them and with other subordinate and $40.58 \%$ teachers responded that they have no good relation with them and with other subordinates.

Table No.03

Is your head teacher cooperative with public and has a social contact?

\begin{tabular}{|l|l|l|l|l|}
\hline No. of Teachers & Yes & No & Yes \%age & No \%age \\
\hline 520 & 257 & 263 & 49.42 & 50.58 \\
\hline
\end{tabular}

Analysis: The table indicates that $49.42 \%$ teachers responded that their head teachers are cooperative with public and has a social contact and 50.58\% teachers responded that they are not cooperative and have no social contact.

Table No.04

Is your head teacher interested to solve your personal problems?

\begin{tabular}{|l|l|l|l|l|}
\hline No. of Teachers & Yes & No & $\begin{array}{r}\text { Yes } \\
\text { \%age }\end{array}$ & No \%age \\
\hline 520 & 114 & 406 & 21.92 & 78.08 \\
\hline
\end{tabular}

Analysis: The table shows that only $21.92 \%$ teachers responded that their head teachers solve their personal problems and $78.08 \%$ teachers responded that their head teachers are not interested to solve their personal problems. 


\section{IIMacrothink}

Table No.05

Is your head teacher interested in school affairs?

\begin{tabular}{|l|l|l|l|l|}
\hline No. of Teachers & Yes & No & $\begin{array}{r}\text { Yes } \\
\% \text { age }\end{array}$ & No \%age \\
\hline 520 & 176 & 344 & 33.85 & 66.15 \\
\hline
\end{tabular}

Analysis: The table indicates that only $33.85 \%$ teachers responded that their head teachers are interested in school affairs and $66.15 \%$ teachers responded that their head teachers are not interested in school affairs.

Table No.06

Does your head teacher solve your teaching and service problems?

\begin{tabular}{|l|l|l|l|l|}
\hline No. of Teachers & Yes & No & Yes $\%$ age & No \%age \\
\hline 520 & 223 & 297 & 42.88 & 57.12 \\
\hline
\end{tabular}

Analysis: The table shows that only $42.88 \%$ teachers responded that their head teachers solve their teaching and service problems and 57.12\% teachers responded that their head teachers do not solve their teaching and service problems.

Table No.07

Does your head teacher has the knowledge to update school record and interested to keep update it?

\begin{tabular}{|l|l|l|l|l|}
\hline No. of Teachers & Yes & No & Yes & No \%age \\
\hline & 277 & 243 & 53.27 & 46.73 \\
\hline
\end{tabular}

Analysis: The table shows that 53.27\% teachers responded that their head teachers have the knowledge to update the school record and interested to keep it update and $46.73 \%$ teachers responded that they are not interested to keep it. 


\section{Table No.8}

Does your head teacher check classes regularly?

\begin{tabular}{|l|l|l|l|l|}
\hline No. of Teachers & Yes & No & Yes & No \%age \\
\hline & 157 & 363 & 30.19 & 69.81 \\
\hline
\end{tabular}

Analysis: the table shows that $30.19 \%$ teachers responded that their head teaches check classes regularly and $69.81 \%$ responded that their head teachers do not check classes regularly.

Table No.09

Does your head teacher invite parents to discuss the student's educational problems?

\begin{tabular}{|l|l|l|l|l|}
\hline No. of Teachers & Yes & No & Yes & No \%age \\
\hline 520 & 203 & 317 & 39.04 & 60.96 \\
\hline
\end{tabular}

Analysis: The table shows that only $39.04 \%$ teachers responded that their head teachers invite parents to discuss the student's educational problems and $60.96 \%$ teachers responded that their head teachers do no invite parents.

Table No.10

Does your head teacher provide facilities for teaching and non-teaching staff?

\begin{tabular}{|l|l|l|l|l|}
\hline No. of Teachers & Yes & No & Yes & No \%age \\
\hline 520 & 152 & 368 & 29.23 & 70.77 \\
\hline
\end{tabular}

Analysis: The table shows that only $29.23 \%$ teachers responded that their head teachers provide facilities for teaching and non-teaching staff and $70.77 \%$ teachers responded that head teachers do not provide facilitates for teaching and non-teaching staff. 


\section{Macrothink}

Table No.11

Does your head teacher supervise school building?

\begin{tabular}{|l|l|l|l|l|}
\hline No. of Teachers & Yes & No & Yes & No \%age \\
\hline 520 & 267 & 253 & 51.35 & 48.65 \\
\hline
\end{tabular}

Analysis: The table shows that $51.35 \%$ teachers responded that their head teachers supervise school building and $48.65 \%$ teachers responded that their head teachers do not supervise school building.

\section{Table No.12}

Does your head teacher take classes with senior classes?

\begin{tabular}{|l|l|l|l|l|}
\hline No. of Teachers & Yes & No & Yes & No \%age \\
\hline 520 & 283 & 237 & 54.42 & 45.58 \\
\hline
\end{tabular}

Analysis: The table shows that $54.42 \%$ teachers responded that their head teachers take classes with senior class and $45.58 \%$ teachers responded that their head teachers do not take classes with senior students.

Table No.13

Does your head teacher correspond with higher authorities?

\begin{tabular}{|l|l|l|l|l|}
\hline No. of Teachers & Yes & No & Yes & No \%age \\
\hline 520 & 221 & 299 & 42.50 & 57.50 \\
\hline
\end{tabular}

Analysis: The table shows that $42.50 \%$ teachers responded that their head teachers correspond with higher authorities and $57.50 \%$ teachers responded that their head teachers do not correspond with higher authorities. 
Table No.14

Is your head teacher punctual and a good disciplinarian?

\begin{tabular}{|l|l|l|l|l|}
\hline No. of Teachers & Yes & No & Yes & No \%age \\
\hline 520 & 216 & 304 & 41.54 & 58.46 \\
\hline
\end{tabular}

Analysis: the table shows that $41.54 \%$ teachers responded that their head teachers are punctual and a good disciplinarian and $58.46 \%$ teachers responded that their head teachers are not punctual and good disciplinarian.

\section{Table No.15}

Does your head teacher has subject mastery and has modern knowledge of teaching methods?

\begin{tabular}{|l|l|l|l|l|}
\hline No. of Teachers & Yes & No & Yes & No \%age \\
\hline 520 & 227 & 293 & 43.65 & 56.35 \\
\hline
\end{tabular}

Analysis: The table shows that $43.65 \%$ teachers responded that their head teachers have subject mastery and has modern knowledge of teaching methods and $56.35 \%$ teachers responded that they have no subject mastery and modern knowledge of teaching method.

Table No.16

Does your head teacher appreciate you on the excellent performance?

\begin{tabular}{|l|l|l|l|l|}
\hline No. of Teachers & Yes & No & Yes & No \%age \\
\hline 520 & 124 & 396 & 23.85 & 76.15 \\
\hline
\end{tabular}

Analysis: The table shows that $23.85 \%$ teachers responded that their head teachers appreciate them on the excellent performance and $76.15 \%$ teachers responded that their head teachers do not appreciate them. 


\section{Macrothink \\ Journal of Public Administration and Governance \\ ISSN 2161-7104 \\ 2011, Vol. 1, No. 2}

Table No.17

Does your head teacher allow you to enjoy extra and unrecorded leaves?

\begin{tabular}{|l|l|l|l|l|}
\hline No. of Teachers & Yes & No & Yes & No \%age \\
\hline 520 & 412 & 108 & 79.23 & 20.77 \\
\hline
\end{tabular}

Analysis: The table shows that $79.23 \%$ teachers responded that their head teachers allow them to enjoy extra and unrecorded leaves and only $20.77 \%$ teachers responded that their head teachers do not allow them to enjoy extra and unrecorded leaves.

Table No.18

Does your head teacher arrange weekly or monthly meetings?

\begin{tabular}{|l|l|l|l|l|}
\hline No. of Teachers & Yes & No & Yes & No \%age \\
\hline 520 & 68 & 452 & 13.08 & 86.92 \\
\hline
\end{tabular}

Analysis: The table shows that $13.08 \%$ teachers responded that their head teachers arrange weekly or monthly meetings and $86.92 \%$ teachers responded that their head teachers do not arrange weekly or monthly meetings.

Table No. 19

Is your head teacher fair in spending school fund?

\begin{tabular}{|l|l|l|l|l|}
\hline No. of Teachers & Yes & No & Yes & No \%age \\
\hline 520 & 205 & 315 & 39.42 & 60.58 \\
\hline
\end{tabular}

Analysis: The table shows that $39.42 \%$ teachers responded that their head teachers are fair in spending school fund and $60.58 \%$ responded that their head teachers are not fair in spending school fund. 


\section{Macrothink}

\section{Conclusions:}

After analysis of the data, the researcher arrived at the following conclusion:

\section{Strong Points:}

1. It was found that majority of the head teachers have a good relation with their subordinate.

2. It was found that majority of the head teachers have the knowledge to update school record and were found interested to keep it update.

3. It was also found that majority of the head teacher supervise school building.

4. It was found that majority of the head teachers take classes with senior classes.

\section{Weak Points:}

1. It was found that majority of the head teachers are not democratic in authority.

2. It was found that majority of the head teacher are not cooperative with public and have no social contact.

3. It was found that majority of the head teachers are not interested to solve teachers personal problems.

4. It was found that majority of the head teachers are not interested in school affairs.

5. It was found that majority of the head teachers do not solve teaching and service problems of teachers.

6. It was found that majority of the head teachers do not check classes regularly.

7. It was found that majority of the head teachers do not invite parents to discuss the student's educational problems.

8. It was found that majority of the head teacher do not provide facilities for teaching and non-teaching staff.

9. It was found that majority of the head teachers do not correspond with higher authorities.

10. It was found that majority of the head teachers are not punctual and not a good disciplinarian.

11. It was found that majority of the head teachers have no subject mastery and no modern knowledge of teaching methods?

12. It was found that majority of the head teachers do not appreciate teachers on the excellent performance. 
13. It was found that majority of the head teachers allow teachers to enjoy extra and unrecorded leaves.

14. It was found that majority of the head teachers do not arrange weekly or monthly meetings.

15. It was also found that majority of the head teachers are not fair in spending school fund.

From the above discussion, it comes to surface that the administrative performance of the head teaches at primary level is very poor, ineffective and objectionable. In the light of above points, it is clear that majority of the head teachers have adopted laissez- faire administration. They do not take interest in the affairs of the schools. They have lack of leadership qualities. The head teachers are responsible for the poor quality of primary education. In nutshell, it is right to say that primary education is collapsing due to poor administrative performance of the head teachers.

\section{Recommendations:}

Keeping in view the conclusions, the researcher makes some recommendations which are described as under:

1. Every primary school should be provided with a class one administrator.

2. Special pay packages should be given to the head of the institutions.

3. Special supervisory staff should be appointed for the inspection of the administrative performance of the head of the institutions.

4. Surprise visits of the officer to primary school should be ensured at least twice in a month.

5. Special training should be provided to the head teachers relating teaching methods and administration.

6. Reward system should be introduced for excellent administrative performance for administrators.

7. Check and Balance system should be ensured at primary level.

8. Competent individuals should be appointed as administrators.

9. It is imperative for administrators to arrange weekly meetings on the schools affairs so that the deficiencies in school should be removed.

10. The administrators should try their best to provide teaching and not teaching facilities to their subordinates. 
11. The administrator should try their best to solve service problems of the teachers.

12. The administrator should keep good relation with public and invite student's parents to school in order to inform them from their children performance.

\section{Recommendations for Future Research Studies:}

1. It is recommended that this type of research should be conducted in other districts and provinces.

2. It is also recommended that this type of research should be conducted at secondary and higher secondary level.

\section{References}

Akpa, G. O. (1999). The teachers factor as a challenge to the success of UBE in Nigeria. A paper presented at the inter-University Collaborative Workshop on Teacher Education in Nigeria at the University of JOS, 6-9 December, 1999.

Campbell, R. F. (1962). Introduction to Educational Administration. Allynbacon, Boston, USA. P.19.

Kenneth, B. B. (1984). Education Administration, Second Edition. Buttler and Tanner Ltd. Great Britain, UK. P.6

Badar, R. and Y. Akhtar. (1991). Sooba Punjab Key Talemi Tanzemi Dhanchy ka Jaiza. Unpublished thesis. University of Punjab, Lahore, Pakistan.

Buracy, M.A. (1958). Administrative Development, An Islamic Perspective. Kagan Paul Ltd, London, U.K. p.227.

Campbell, R. F. (1962). Introduction to Educational Administration. Allynbacon, Boston, USA. P.19

Govt. of Pakistan, (1998). National Educational Policy 1998-2010. Ministry of education, Islamabad. p.17.

Gupta, L.D. (1987). Educational Administration. Oxford \&IBH Publishing Co. Pvt. New Delhi.

Hunt, H.G \& Pierce, P.R. (1958). The Practice of School Administration. Houghton Mifflin Company, Boston.

Kenneth, B. B. (1984). Education Administration, Second Edition. Buttler and Tanner Ltd. Great Britain, UK. P.6 


\section{Macrothink}

Journal of Public Administration and Governance ISSN 2161-7104 2011, Vol. 1, No. 2

Khan, M. A. (1998). An Appraisal of Supervisory Practices in the Schools of District Attock. Unpublished thesis, University of Arid Agriculture, Rawalpindi, Pakistan pp.13-14.

Mohanty, J. (1998). Educational Administration Supervision and School Management. Oxford \& IBH Publishing Co. Pvt. Ltd., New Delhi.

Musaazi, J.C.S. (1998). The Theory and Practice of Educational Administration. 